\title{
Understanding the Strategy-Innovation Link in an Era of Disruptions
}

Karl Joachim Breunig \& Tale Skjølsvik

\author{
" The best way to predict the future is to create it." \\ Peter Drucker
}

\begin{abstract}
Whereas innovation and strategy traditionally are treated as two separate fields of expertise and research, this conceptual paper aims to identify how strategy theory can be linked to recent developments within the innovation field. Innovation research seeks to explain the process of creating new products and services. Strategy research, in turn, intends to explain how businesses create lasting competitive advantages. In recent years, research in strategy has shifted towards explaining how organizational capabilities and environmental turbulence are related, increasingly recognizing that it is difficult to retain sustainable competitive advantages, unless market dynamics and business renewal are addressed. To establish a systematic integration and analysis, we present the results of an extensive literature review of 1,268 research articles published between 2007-2017 to address the question: To what degree, and how, have strategy and innovation been linked in leading management journals? Our analysis reveals that research addressing both strategy and innovation is limited, but highly cited. Moreover, we identify 5 main themes, which in turn reflected 12 subsidiary themes addressed in extant research. These themes combine to give important insights about the research that been done and what is likely to be needed going forward.
\end{abstract}

\section{Introduction}

The essential role of innovation and entrepreneurship in the sustainability of a firm's competitiveness was pointed out by Schumpeter (1949). However, it remains conceptually unclear how extant strategy frameworks explicitly integrate and build on a Schumpeterian paradigm. Despite efforts to develop an improved understanding of how strategy and innovation theory can be integrated (e.g. Ramanujam \& Mensch, 1985; Pisano, 2015; Teece et al. 2016), strategy theory has only to a limited degree become fused with ideas from innovation theory. In a contemporary business environment where the biggest and most valuable technology firms (FAANG: Facebook, Apple, Amazon, Netflix, and Google) are distinguished by their innovation capacity and capability, it is problematic that innovation activities predominantly remain outside the strategy theory domain.

To fill this void, we offer the results from a structured literature search in the Web of Science and EBSCO databases that attempt to integrate strategy and innovation research. In particular we review the highest ranked journals in the area of innovation and strategy from 2007-2017 and map to what degree and how innovation and strategy have been treated together in prior research. We identify themes covered in this research and reveal that the papers that link these research areas are extensively cited. Still, a lot of work remains to be done, and fusing core properties of strategy theory with recent ideas from innovation literature we believe is both obtainable and prudent at the present time.

The structure of this paper can be described as follows. First, we present extant strategy and innovation management theory to highlight similarities and differences across these two bodies of research and pose our research question. Second, we explain the method applied in the search, review, and analysis of the reviewed papers. Third, we present the findings from our analysis of the extant body of literature addressing strategy and innovation. And, finally, we offer a concluding discussion with implications on future developments for research and practice.

\section{Theory}

Going back to Schumpeter and the notion of 'creative destruction' (Schumpeter, 1949), the need for innovation 


\section{Understanding the Strategy-Innovation Link in an Era of Disruptions Karl Joachim Breunig \& Tale Skjølsvik}

and entrepreneurship is recognized in most firms as a way to guarantee their sustained competitiveness. However, innovation and strategy have traditionally been treated as two separate fields of expertise and research. Innovation research seeks to explain the process of creating new products and services (Burns \& Stalkers, 1961). Innovation is largely regarded as a social process consisting of three core activities (Newell et al., 2009). The first activity is the generation of new solutions, also referred to as 'invention'. Then the act of diffusion follows, which denotes the process of spreading the new solution to other individuals so that they also get an understanding of it. Finally, the innovation process depends on implementation, that is, other individuals and communities also start using the new solution.

Innovation strategy refers to articulating the role of innovation in achieving organizational aims (Cooper, 2001), by aligning the overall business strategy with innovation decisions (Menor \& Roth, 2007). Recent innovation management research has documented how firms utilize their resources and capabilities for the development of innovations, such as new products, services, or processes (Hill et al., 2015), and explicitly link resources and processes to innovation success (Froehle \& Roth, 2007; Aas et al., 2015). Furthermore, research has shown a positive relationship between the implementation of innovation activities and future business performance (Bowen et al., 2010; Rubera \& Kirca, 2012). Indeed, several authors (Easingwood, 1990; Johne \& Storey, 1998) stress that it is important to set clear goals for the innovation program as a whole. Empirical studies similarly suggest that leading firms are likely to have an explicit innovation strategy (Cooper et al., 2002). In recent years, the focus of research on innovation management has primarily been concerned with innovations related to physical products (Droege et al., 2009), while limited work has also been done to systematically review and categorize the different attempts to create a more explicit strategy-innovation link.

In contrast, strategy research aims to explain how businesses create lasting competitive advantages (Porter, 1985). The field of strategic management is nevertheless fragmented and overlaps with a number of theoretical fields, such as economics, sociology, marketing, finance, and psychology (Nag et al., 2007). In the late 1970s, the field was in its infancy and relabelled from 'business policy' (Schendel \& Hofer,
1979). Due to the diversity of the field, a coherent established definition of strategic management has been lacking (Mintzberg et al., 1998). Based on a major survey of other scholars' research, Nag et al. (2007) defined 'strategic management' as "intended and emergent initiatives, taken by managers or on behalf of the owners, involving utilization of resources, to enhance the performance of firms in their external environment".

Strategic management research was in its early days largely rooted in what is referred to as the StructureConduct-Performance tradition. It is most notably captured in Porter's influential contributions (Porter, 1980, 1985), in which competitive advantage is assumed to be based on industry or strategic group, a group of companies within the same industry that have a similar strategic profile, and are only to a limited degree linked to innovation. In parallel, Mintzberg and colleagues (Mintzberg, 1978; Mintzberg \& Waters, 1985; Mintzberg \& McHugh, 1985) argued for an alternative view on strategic management, proposing that not all formal strategies are implemented as intended, and that many implemented strategies emerge from outside of the scope of ex ante analyses and plans. Innovation was thus not a key orientation of these earlier theories on strategy.

More recently, research in strategy has shifted towards explaining how organizational capabilities and environmental turbulence are related, increasingly recognizing that it is difficult to retain sustainable competitive advantages unless market dynamics and business renewal are considered (Teece et al., 1997). Given rapid market changes and innovation pressure, caused for example by digitalization, an explication of how strategy relates to innovation is needed. To succeed in a globalized business environment characterized by hyper-velocity (Francis \& Bessant, 2005; Crossan \& Apaydin, 2010), it has been claimed that organizations need to manage change in increasingly volatile and complex service eco-systems (Yoo \& Kim, 2015). Under such conditions, dynamic capabilities possessed by firms have been linked to their sustained competitiveness (Eisenhardt, 2004), and claimed to be central to innovation (Tidd, 2012). However, the ability to replicate dynamic capabilities and innovation success over time has not been firmly established in extant research.

In the early 2000s, an entrepreneurial perspective on strategy gained ground, emphasizing value creation rather than appropriation (Hitt et al., 2001). The multiplicity and complexity of strategic management, as 


\section{Understanding the Strategy-Innovation Link in an Era of Disruptions Karl Joachim Breunig \& Tale Skjølsvik}

well as the need to consider balances and paradoxes, have also been recognized in recent strategy research. Some examples include dealing with business ambidexterity (Tushman \& O’Reilly, 1996; Birkinshaw \& Gibson, 2004) by balancing exploration (innovation) and exploitation (the productivity of existing solutions and products), and managing paradoxes (Eisenhardt, 2000). Still, strategy theory has to a limited degree been fused with ideas from innovation theory (Markides, 2006; Lightfoot \& Gebauer, 2011; Pisano, 2015; Teece et al., 2016). The blue ocean strategy (Kim \& Mauborgne, 2004), business model innovation (Christensen \& Johnson, 2009; Teece, 2010; Osterwalder \& Pigneur, 2010; Zott et al., 2011; Foss and Saebi, 2017), dynamic capabilities (Kogut \& Zander, 1992; Barnett et al., 1994; Teece et al., 1997; Eisenhardt \& Martin, 2000, Helfat \& Peteraf, 2003), and disruption theory (Christensen, 1997; Markides, 2006; Manyika et al., 2013; O’Reilly III \& Tushman, 2016) are notable exceptions.

\section{Methods}

The aim of this study is to review research that aims to bridge strategy and innovation in highly ranked journals. In doing this, we took an inductive approach, with both qualitative and quantitative analysis. This approach enabled us to develop a solid understanding of the areas where strategy and innovation has been interlinked. It also enabled us to tease out dominant themes in this research, as well as potential avenues for future research.

\subsection{Data collection and compilation}

In doing a systematic literature review, one typically goes through three main phases: planning, which involves the identification of the research question and defining boundaries; conducting, which involves searching for and analysis of relevant literature; and reporting, that is, formalizing the findings and developing implications (Tranfield et al., 2003; Ashby et al., 2012). The first two phases will be described here, while the third phase is described in the Findings section.

In the planning phase, we first formulated our research question. We then defined the boundaries of our study to include academic articles published during the period 2007-2017 in the eight top strategy and innovation journals globally, as listed by 2015 Association of Business Schools academic journal guide (ABS list) (Harvey, 2012). The ABS-list has separate categories for both innovation and strategy with four top journals at level 4 in each field. These journals are for strategy: Strategic Management Journal, Global Strategy Journal, Long Range Planning, and Strategic Organization; and for innovation: Journal of Product Innovation Management, Research Policy, R\&D Management, and Technovation.

The ABS list is the most comprehensive and frequently used ranking list among business research scholars around the world when choosing publication outlets. It is the dominant source used to evaluate business research across Europe and the US. Thus, limiting the scope of journals to the ABS list suggests that the research included in the literature review is likely to be of high quality and reliability.

After having identified the research question and the scope of the study, we continued to the conducting phase. In this phase it was important to develop a database of articles that integrates innovation and strategy. In doing so, we used The Web of Science Social Sciences Citation Index (SSCI). Due to different search categories and search methods, we had to use different search terms across databases. We used the search terms innovati* strateg*, where the asteric means all words that include this start, thus allowing 'strategic' and 'strategy' as well as 'innovative' and 'innovation' to be part of the search. Our investigation covered a search term in Web of Science referred to as Topic, which includes abstract, author keywords, and Keywords Plus, the latter which are index terms created by database managers based on frequently occurring words in the titles of references cited in an article. Thus, our search basically covered all relevant available information in Web of Science, as full text searches are not possible.

The search resulted in a total of 1,268 hits. To limit the scope of the qualitative analysis and to ensure relevance of the included papers, only papers with both strategy and innovation in the abstract among these papers were compiled into a separate dataset of 381 papers. This was done by using the EBSCO database, which allows for specific searches in the abstract, a function not available in Web of Science.

\subsection{Data analysis}

The data analysis included both quantitative and qualitative components. In particular, the analysis was conducted in two main phases: 1) familiarization and description of the data based on quantitative methods, and 2) identification and analysis of key research themes based on qualitative methods and descriptive 


\section{Understanding the Strategy-Innovation Link in an Era of Disruptions Karl Joachim Breunig \& Tale Skjølsvik}

quantitative analysis of the identified themes. In the familiarization phase, we developed an overview of the research that include both innovation and strategy. In particular, the following variables was mapped: 1) number of papers over time, 2) emphasis across journals, and 3) citations. These could be directly mapped form the results of the search. In addition, we did qualitative analysis in order to classify the different papers. This was done based on a classification of the content of the abstract. In particular, each abstract was first classified inductively and based on a research centric orientation, following Gioia et al. (2013). In turn, these classifications were further compared to research-based themes and classified at a more aggregate level for comparison. To the degree that the abstract mentioned theory and methodology used in the paper, it was included in the classification of the paper and added to the database.

\section{Findings}

The findings will be presented in the two parts: (1) A descriptive overview of number of papers, journals and citations over time, and (2) The main themes covered in the research, including count.

\subsection{Descriptive overview of papers}

The number of papers in this area has been relatively stable over time, with some fluctuation over the last 4 years. The general trend is a slight increase, but no significant trend. Among other reasons, this is partly caused by the limited number of journals that cover this area, in which only so many papers are published every year. Please see figure 1 for a general overview of the data over time. In the figure, the Web of Science search as explained above covers the 1,268 papers, while the EBSCO search only incorporates the 381 papers with

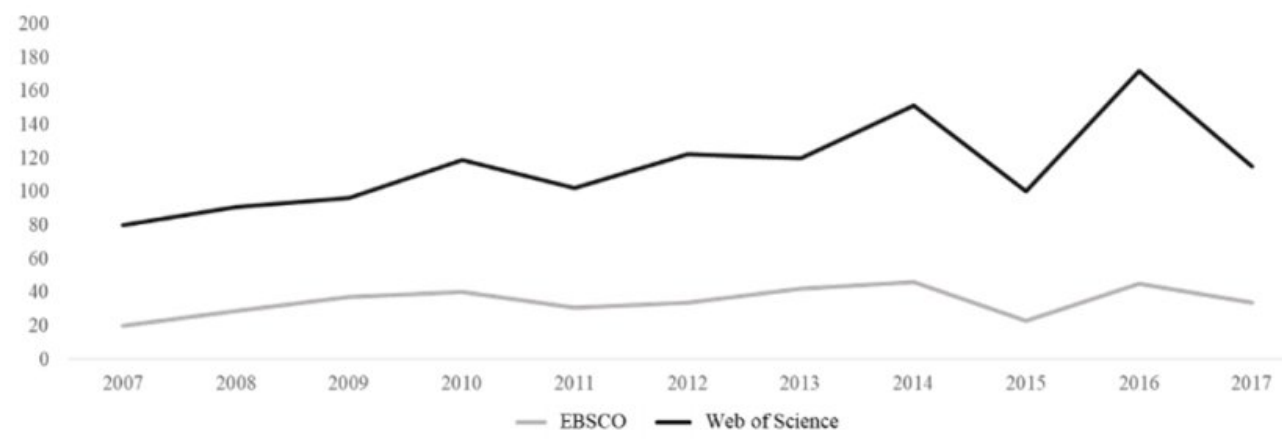

Figure 1. Overview of number of selected publications over time

both innovation and strategy in the abstract. The trend of greater elaboration and a database with both innovation and strategy in the abstract is very similar.
In terms of the types of journals covered in the search, the top journals within the innovation discipline seemed to consider strategy to be an important area of research.

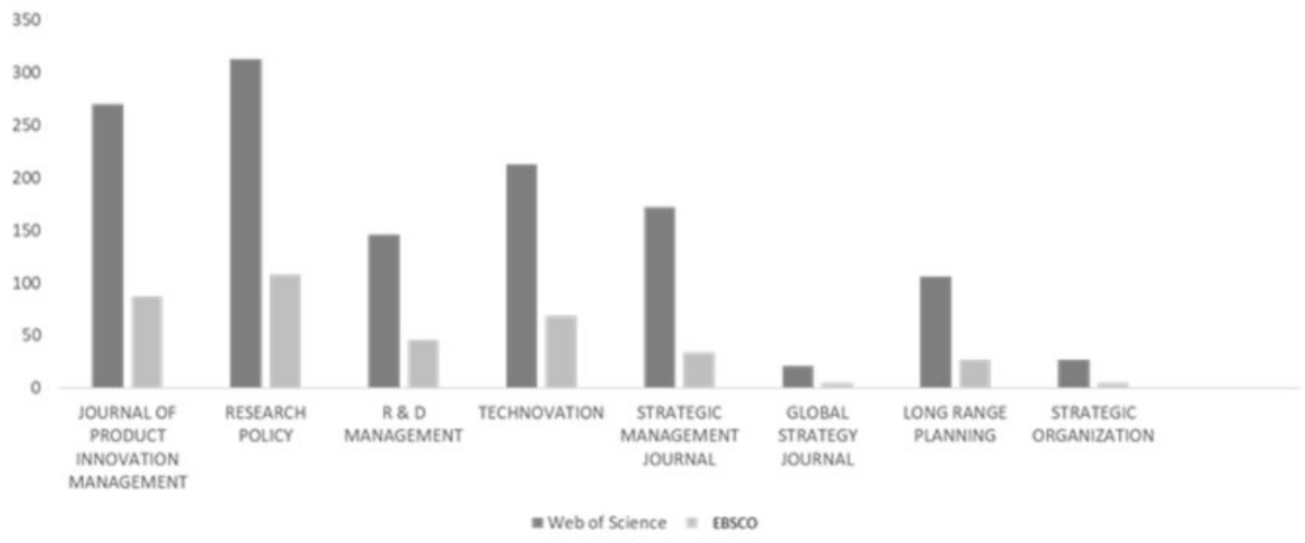

Figure 2. Overview of identified publications per selected journal 


\section{Understanding the Strategy-Innovation Link in an Era of Disruptions Karl Joachim Breunig \& Tale Skjølsvik}

In contrast, primarily only two of the top strategy journals have papers that link strategy and innovation, while interest within the field of strategy is much more limited. Figure 2 provides an overview of the identified publications outlets.

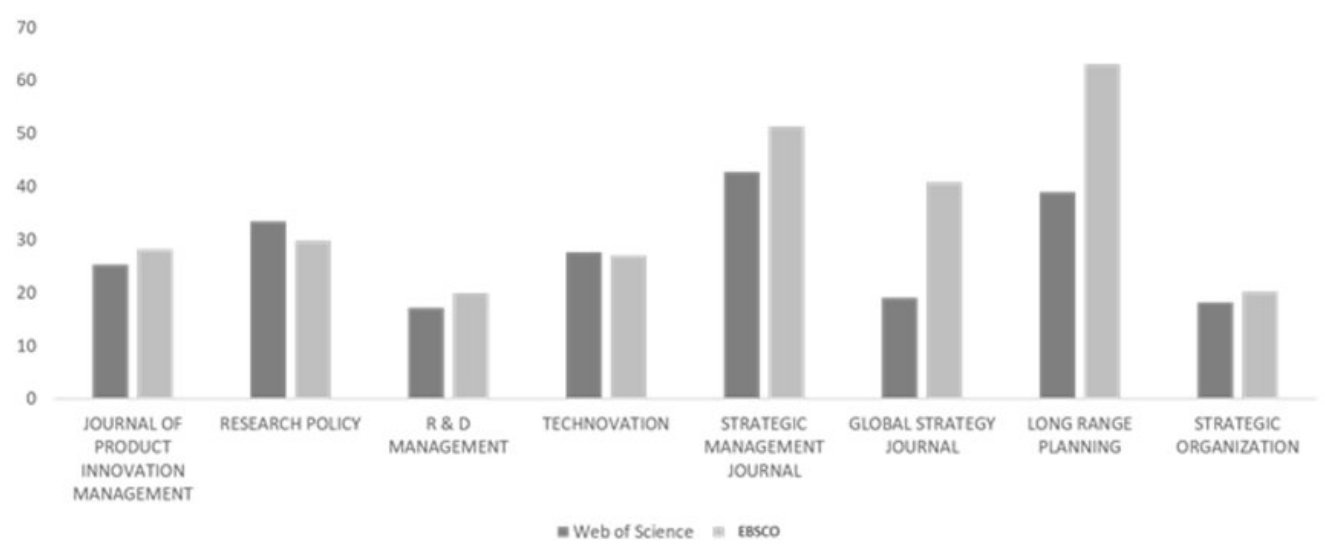

Figure 3. Overview of selected journals measured in citations (March 2018)

When one looks at the impact of research that has been done that deals with both innovation and strategy, the average citation rate in all the journals is very high. Thus, scholars in other fields have shown interest in the work that is being done in this area.

Figure 3 shows that the average number of citations per paper is extremely high for papers that cover both areas. As the selection of papers gets more narrow - as in the case where only papers with the concepts of innovation and strategy in the abstract is included - the number of citations in 6 out of 8 journals increase. Further, the number of citations in the strategy journals is considerably higher than in the innovation journals.

\subsection{The main themes covered in the research}

Through a tedious classification process explained under that data analysis section above, the 381 papers were inductively reduced into 5 main themes, which in turn reflected 12 subsidiary themes. Of these 5 themes, 3 of them was primarily oriented towards innovation and marketing with a more limited relevance to strategy. These were: conditions of ecosystem, business relationships and policies, fundamentals in terms of governance and technology, and value creation in terms of design, product, and customer. Additionally, two areas were identified that illustrated the bridge between strategy and innovation as opposed to emphasizing primarily one over the other: value appropriation in terms of the choice of an open versus protected

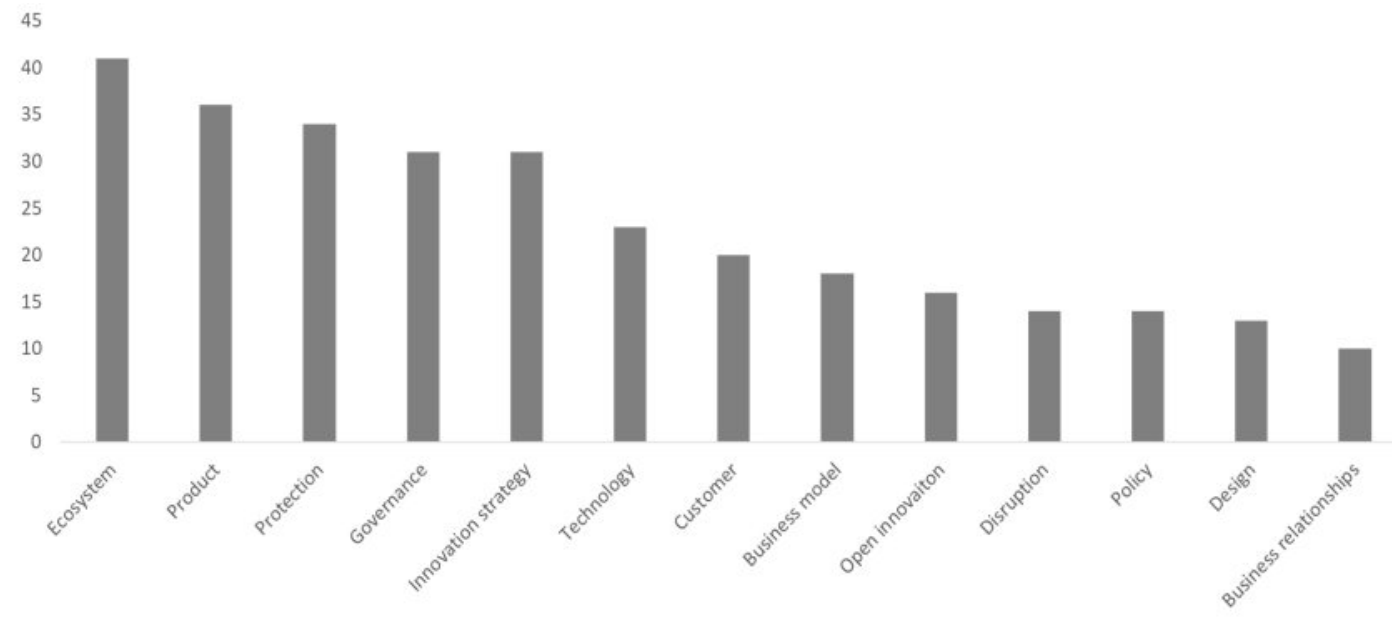

Figure 4. Overview of identified themes 


\section{Understanding the Strategy-Innovation Link in an Era of Disruptions Karl Joachim Breunig \& Tale Skjølsvik}

approach to innovation, and the strategy-innovation link, which includes business models, innovation strategy, and disruption.

\subsection{The strategy-innovation link}

The research where strategy and innovation are linked concerns 3 main areas: business models, disruption and innovation strategy. Business models had the highest total number of citations, with an average of 79 citations per publication. Of the 18 publications, a conceptual paper by Teece (2010) was cited 1,047 times and largely drives this number, as a seminal paper on business models. For the rest of the papers, the average number of citations was 21. Many of these papers are relatively recent and all the papers were published between 2010-2017. In particular, various papers deal with the concept of a business model (Baden-Fuller \& Morgan, 2010; Teece, 2010; DaSilva \& Trkman, 2014) and different ways of making innovations in the business model, for example, based on pricing and payment models as well as resources (Corrocher and Zirulia, 2010; Denicolai et al., 2014; Winterhalter et al., 2017). Some of the later contributions, (Spieth et al., 2014; Cortimiglia et al., 2016) identify the interlinkage between business models and strategy-making.

In addition to business models, innovation strategy is mentioned as a key area. This area emphasizes several different strategic decisions that companies need to make in their innovation efforts. In particular, it concerns short and long term decisions in $\mathrm{R} \& \mathrm{D}$ (Artés, 2009; Flammer \& Bansal, 2017), the decision to exploit versus explore knowledge ( Hernández-Espallardo et al., 2011; Bauer \& Leker, 2013; Piao \& Zajac, 2016; Enkel et al., 2017), internal versus external $R \& D$ resources (Hagedoorn \& Wang, 2012), and whether to offshore R\&D activities (Nieto \& Rodríguez, 2011; Rodríguez \& Nieto, 2012; Steinberg et al., 2017).

Finally, disruption deals with how existing industries face disruptive business models or technology innovations. A lot of what has been written with regards to strategy and innovation in this area deals with incumbent reactions (Awate et al., 2012; Huesig et al., 2014) and the role of the government (Ruan et al., 2014).

\subsection{Value appropriation}

In addition to the direct link between strategy and innovation in existing research, the literature points to value appropriation as an essential area of research where these fields are integrated. In particular it deals with the strategic difference it makes in an organization when it comes to choosing openness or protectionism, which seems rooted in the dichotomy of a relational versus a transactional orientation in organization. Two main areas have gained interest: patents and intellectual properly strategy (IPS) versus open innovation. These areas stand in strong contrast in most cases and represent an important strategic choice in the area of innovation strategy.

With regards to open innovation, a number of areas have been studied, such as motivations (Appleyard \& Chesbrough, 2017) and trade-offs between openness and protection (Raasch et al., 2009; Knudsen \& Mortensen, 2011). In the area of IP protection, several papers have dealt with how organizations make protection decisions (Gallié \& Legros, 2012), the use of licensing (Gallié \& Legros, 2012; Großmann et al., 2016), standard catch-up collection and use of patents (Schmidt, 2013; Jell et al., 2017).

\section{Discussion}

Most contemporary organizations face challenges related to achieving sustainability and advantages in periods of market change. This is particularly salient in times of digital disruption and in the face of the so-called '4th industrial revolution'. These changes demand innovation to be integrated as a central part of a company's organizational strategy. In addressing the societal level, a key emphasis is now placed on 'ecosystems' and 'value networks', with extensive research focusing on the innovation context beyond organizations, such as within cross-organizational collaboration or caused as a response to particular policies and regulation. At this level, the main focus is on innovation theory, which has identified a few links to strategy theory.

At the organizational level, business strategy is increasingly being merged with the core properties of innovation theory, which are to obtain scalability and differentiation into "blue ocean strategies". Likewise, visionary and transformative leadership styles are merging with ideas from entrepreneurship research to address creativity and values. At the value creation and appropriation level, the core issue relates to protection of innovation advantages, where open source innovation and a proprietary approach stand in strong contrast to each other. This value creation and appropriation 


\section{Understanding the Strategy-Innovation Link in an Era of Disruptions Karl Joachim Breunig \& Tale Skjølsvik}

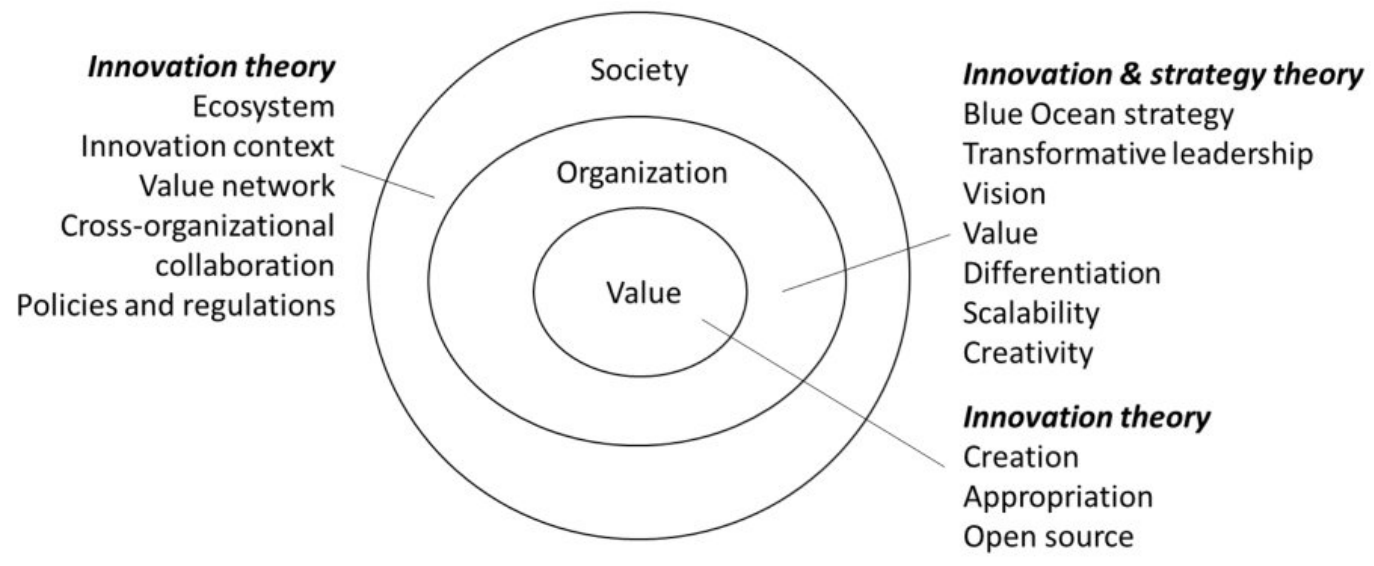

Figure 5. Levels and details of the strategy-innovation link

tradition is also largely rooted in innovation theory tradition. These different levels are illustrated in Figure 5.

The core of the strategy-innovation link incorporates a combination of theories that directly look at business models, disruption, and innovation. Future research should use these different levels to further develop an understanding of how innovation can be transformed into and integrated with strategy.

\section{Conclusion}

In this study we have conducted a structured literature review to assess to what degree strategy and innovation have been linked in research conducted in leading management journals. The analysis shows that links between the two main concepts have been made at three different levels of analysis: 1) at the societal level, 2) the organizational level, and finally 3 ) at the value creation and appropriation level. Additionally, the review shows a theoretical link between the concepts business model, disruption, and strategy innovation.

By discussing how innovation and market characteristics affect business strategy, the paper contributes to knowledge on the strategy-innovation link. The conclusions reported here may provide considerable assistance to managers who are searching for better ways to develop strategy and manage their organizations, while increasing their innovative abilities and capacities. By pointing to different theoretical positions, managers can get a sense of which theoretical perspectives to consider in their efforts to develop their organizations into the future. While strategy in many organizations has up until now used analyses in the form of five forces, the Boston Consulting Group's (BCG) matrix, the resource based view of the firm, and other approaches, we believe that managers in the future should think freshly in terms of the types of theories they build their strategy work on, if one of their key objectives is value creation and innovation, as opposed to value appropriation. The paper suggests that as innovation to a larger degree becomes a key objective in many saturated organizations under conditions of change, business model theory, disruption theory, and innovation strategy should take place as core theoretical perspectives for organizations in their strategy processes.

Nevertheless, the conceptual nature of the study has limitations and further empirical research is needed to explore and test if the conclusions of the discussion are to reach beyond the provided categories. 


\section{Understanding the Strategy-Innovation Link in an Era of Disruptions \\ Karl Joachim Breunig \& Tale Skjølsvik}

\section{References}

Aas, T.H., Breunig, K.J., Hydle, K.M. \& Pedersen, P. 2015. Innovation Management Practices in ProductionIntensive Services: An Exploratory Investigation. International Journal of Innovation Management, 19: 1-28.

Appleyard, M.M. \& Chesbrough, H.W. 2017. The Dynamics of Open Strategy: From Adoption to Reversion. Long Range Planning, 50: 310-321.

Artés, J. 2009. Long-Run Versus Short-Run Decisions: R\&D and Market Structure in Spanish Firms. Research Policy, 38: 120-132.

Ashby, A., Leat, M. \& Hudson-Smith, M. 2012. Making Connections: A Review of Supply Chain Management and Sustainability Literature. Supply Chain Management: An International Journal, 17: 497-516.

Awate, S., Larsen, M.M. \& Mudambi, R. 2012. Emne Catch Up Strategies in the Wind Turbine Industry: Is There a Trade Off Between Output and Innovation Capabilities? Global Strategy Journal, 2: 205-223.

Baden-Fuller, C. \& Morgan, M.S. 2010. Business Models as Models. Long Range Planning, 43: 156-171.

Barnett, W. P., Greve, H.R. \& Park, D. Y. 1994. An Evolutionary Model of Organizational Performance. Strategic Management Journal, 15: 11-28

Bauer, M. \& Leker, J. 2013. Exploration and Exploitation in Product and Process Innovation in the Chemical Industry. R\&D Management, 43: 196-212.

Birkinshaw, J. \& Gibson, C. 2004. Building Ambidexterity into an Organization. Academy of Management Journal, 47: 209-226.

Bowen, F.E., Rostami, M. \& Steel, P. 2010. Timing is Everything: A Meta-Analysis of the Relationships Between Organizational Performance and Innovation. Journal of Business Research, 63: 11791185.

Burns, T. \& Stalkers, G.M. 1961. The Management of Innovation. Oxford University Press.

Christensen, C.M. 1997. The Innovator's Dilemma: When New Technologies Cause Great Firms to Fail. Harvard Business School Press.

Christensen, C.M. \& Johnson, M.W. 2009. What Are Business Models, And How Are They Built? Harvard Business School, Module Note 610-019, August.

Cooper, R.G. 2001. Winning at New Products: Accelerating The Process From Idea To Launch, 3rd Edition. Cambridge, Perseus Publishing.

Cooper, R.G., Edgett, S.J. \& Kleinschmidt, E.J. 2002. Optimizing the Stage-Gate Process: What BestPractice Companies Doing. Research Technology Management, 45: 21-27.
Corrocher, N. \& Zirulia, L. 2010. Demand and Innovation in Services: The Case of Mobile Communications. Research Policy, 39: 945-955.

Cortimiglia, M.N., Ghezzi, A. \& Frank, A.G. 2016. Business Model Innovation and Strategy Making Nexus: Evidence from a Cross Industry Mixed Methods Study. R\&D Management, 46: 414432.

Crossan, M.M. \& Apaydin, M. 2010. A Multi Dimensional Framework of Organizational Innovation: A Systematic Review of the Literature. Journal of Management Studies, 47: 1154-1191.

Dasilva, C.M. \& Trkman, P. 2014. Business Model: What it is and What it is not. Long Range Planning, 47: 379389.

Denicolai, S., Ramirez, M. \& Tidd, J. 2014. Creating and Capturing Value from External Knowledge: The Moderating Role of Knowledge Intensity. $R \& D$ Management, 44: 248-264.

Droege, H., Hildebrand, D. \& Forcada, M.A.H. 2009. Innovation in Services: Present Findings, and Future Pathways. Journal of Service Management, 20: 131155.

Easingwood, C.J. Service Design and Service Strategies. 1990. First International Research Seminar in Service Management. Institute D'administration Des Enterprises, Aix-En-Provence, France: 188-190.

Eisenhardt, K.M. 2000. Paradox, Spirals, Ambivalence: The New Language of Change and Pluralism. Academy of Management Review, 25: 703-705.

Eisenhardt, K.M. 2004. Speed and Strategic Change: How Managers Accelerate Decision Making. In: Katz, R. (Ed.) The Human Side of Managing Technological Innovation. New York: Oxford University Press.

Eisenhardt, K.M. \& Martin, J.A. 2000. Dynamic Capabilities: Why are They? Strategic Management Journal, 21: 1105-1121.

Enkel, E., Heil, S., Hengstler, M. \& Wirth, H. 2017. Exploratory and Exploitative Innovation: To What Extent Do the Dimensions of Individual Level Absorptive Capacity Contribute? Technovation, 60: 29-38.

Flammer, C. \& Bansal, P. 2017. Does a Long-Term Orientation Create Value? Evidence from a Regression Discontinuity. Strategic Management Journal, 38: 1827-1847.

Foss, N.J. \& Saebi, T. 2017. Fifteen Years of Research on Business Model Innovation: How Far Have We Come, and Where Should We Go? Journal of Management, 43: 200-227.

Francis, D. \& Bessant, J. 2005. Targeting Innovation and Implications for Capability Development. Technovation, 25: 171-183. 


\section{Understanding the Strategy-Innovation Link in an Era of Disruptions Karl Joachim Breunig \& Tale Skjølsvik}

Froehle, C.M. \& Roth, A.V. 2007. A Resource-Process Framework of New Service Development. Production and Operations Management, 16, 169-188.

Gallié, E.-P. \& Legros, D. 2012. French Firms' Strategies for Protecting Their Intellectual Property. Research Policy, 41: 780-794.

Gioia, D.A., Corley, K. G. \& Hamilton, A.L. 2013. Seeking Qualitative Rigor in Inductive Research Notes on The Gioia Methodology. Organizational Research Methods, 16: 15-31.

Großmann, A.M., Filipovi , E. \& Lazina, L. 2016. The Strategic Use of Patents and Standards for New Product Development Knowledge Transfer. $R \& D$ Management: 46, 312-325.

Hagedoorn, J. \& Wang, N. 2012. Is There Complementarity or Substitutability Between Internal and External R\&D Strategies? Research Policy, 41: 1072-1083.

Harvey, J. F. 2012. Managing Organizational Memory with Intergenerational Knowledge Transfer. Journal Of Knowledge Management, 16: 400-417.

Helfat, C.E. \& Peteraf, M.A. 2003. The Dynamic Resource-Based View: Capability Lifecycles. Strategic Management Journal, 24: 997-1010.

Hernández-Espallardo, M., Sánchez-Pérez, M. \& Segovia-López, C. 2011. Exploitation- and Exploration-Based Innovations: The Role of Knowledge in Inter-Firm Relationships with Distributors. Technovation, 31: 203-215.

Hill, L.A., Brandeau, G., Truelove, E. \& Lineback, K. 2015. The Capabilities Your Organization Needs to Sustain Innovation. Harvard Business Review.

Hitt, M.A., Bierman, L., Shimizu, K. \& Kochhar, R. 2001. Direct and Moderating Effects of Human Capital on Strategy and Performance in Professional Service Firms: A Resource-Based Perspective. Academy of Management Journal, 44: 13-28.

Huesig, S., Timar, K. \& Doblinger, C. 2014. The Influence of Regulation and Disruptive Potential on Incumbents' Submarket Entry Decision and Success in the Context of a Network Industry. Journal of Product Innovation Management, 31: 1039-1056.

Jell, F., Henkel, J. \& Wallin, M.W. 2017. Offensive Patent Portfolio Races. Long Range Planning, 50: 531-549.

Johne, A. \& Storey, C. 1998. New Service Development: A Review of the Literature and Annotated Bibliography. European Journal of Marketing, 32: 184.

Kim, W.C. \& Mauborgne, R. 2004. Blue Ocean Strategy. Harvard Business Review: 76-84.

Knudsen, M.P. \& Mortensen, T.B. 2011. Some Immediate-But Negative-Effects of Openness on Product Development Performance. Technovation, 31: 54-64.

Kogut, B. \& Zander, U. 1992. Knowledge of the Firm, Combinative Capabilities, and the Replication of Technology. Organization Science, 3: 383-398.
Lightfoot, H.W. \& Gebauer, H. 2011. Exploring the Alignment Between Service Strategy and Service Innovation. Journal of Service Management, 22: 664683.

Manyika, J., Chui, M., Bughin, J., Bisson, P. \& Marrs, A. 2013. Disruptive Technologies: Advances That Will Transform Life, Business, and the Global Economy. San Fransisco, Ca, Us: Mckinsey Global Institute.

Markides, C. 2006. Disruptive Innovation: In Need of Better Theory. Journal of Product Innovation Management, 23: 19-25.

Menor, L.J. \& Roth, A.V. 2007. New Service Development Competence in Retail Banking: Construct Development and Measurement Validation. Journal of Operations Management, 25: 825-846.

Mintzberg, H. 1978. Patterns in Strategy Formation. Management Science, 24: 934-948.

Mintzberg, H., Ahlstrand, B. \& Lampel, J. 1998. Strategy Safari. London, Prentice Hall.

Mintzberg, H. \& Mchugh, A. 1985. Strategy Formation in an Adhocracy. McGill University.

Mintzberg, H. \& Waters, J.A. 1985. of Strategies, Deliberate and Emergent. Strategic Management Journal, 6: 257-272.

Nag, R., Hambrick, D.C. \& Chen, M.-J. 2007. What is Strategic Management, Really? Inductive Derivation of a Consensus Definition of the Field. Strategic Management Journal, 28: 935-955.

Newell, S., Robertsen, M., Scarbrough, H. \& Swan, J. 2009. Managing Knowledge Work and Innovation. Basingstoke, Palgrave Macmillan.

Nieto, M.J. \& Rodríguez, A. 2011. Offshoring of R\&D: Looking Abroad to Improve Innovation Performance. Journal of International Business Studies, 42: 345-361.

O'Reilly Iii, C.A. \& Tushman, M.L. 2016. Lead and Disrupt: How to Solve the Innovator's Dilemma. Stanford University Press.

Osterwalder, A. \& Pigneur, Y. 2010. Business Model Generation: A Handbook for Visionaries, Game Changers, and Challengers. John Wiley \& Sons.

Piao, M. \& Zajac, E.J. 2016. How Exploitation Impedes and Impels Exploration: Theory and Evidence. Strategic Management Journal, 37: 1431-1447.

Pisano, G.P. 2015. You Need an Innovation Strategy. Harvard Business Review, 93: 44-54.

Porter, M.E. 1980. Competitive Strategy. New York, Free Press.

Porter, M.E. 1985. Competitive Advantage: Creating and Sustaining Superior Performance. New York, The Free Press.

Raasch, C., Herstatt, C. \& Balka, K. 2009. On the Open Design of Tangible Goods. R\&D Management, 39: 382-393. 


\section{Understanding the Strategy-Innovation Link in an Era of Disruptions Karl Joachim Breunig \& Tale Skjølsvik}

Ramanujam, V. \& Mensch, G. O. 1985. Improving the Strategy-Innovation Link. Journal of Product Innovation Management, 2: 213-223.

Rodríguez, A. \& Nieto, M.J. 2012. The Internationalization of Knowledge-Intensive Business Services: The Effect of Collaboration and the Mediating Role of Innovation. Service Industries Journal, 32: 1057-1075.

Ruan, Y., Hang, C.C. \& Wang, Y.M. 2014. Government's Role in Disruptive Innovation and Industry Emergence: The Case of the Electric Bike in China. Technovation, 34: 785-796.

Rubera, G. \& Kirca, A.H. 2012. Firm Innovativeness and its Performance Outcomes: A Meta-Analytic Review and Theoretical Integration. Journal of Marketing, 76: $130-147$.

Schendel, D. \& Hofer, C.W. 1979. Strategic Management: A New View of Business Policy and Planning. Little, Brown.

Schmidt, M.P. 2013. Patent Strategies in the Process Related Industries: Outline of the Problems. R\&D Management, 43: 242-251.

Schumpeter, J.A. 1949. Economic Theory and Entrepreneurial History, from Change and the Entrepreneur. Cambridge, Ma., Harvard University Press.

Spieth, P., Schneckenberg, D. \& Ricart, J.E. 2014. Business Model Innovation-State of the Art and Future Challenges for the Field. R\&D Management, 44: 237-247.

Steinberg, P.J., Procher, V.D. \& Urbig, D. 2017. Too Much or Too Little of R\&D Offshoring: The Impact of Captive Offshoring and Contract Offshoring on Innovation Performance. Research Policy, 46: 18101823.

Teece, D. 2010. Business Models, Business Strategy and Innovation. Long Range Planning, 43: 172-194.

Teece, D., Peteraf, M. \& Leih, S. 2016. Dynamic Capabilities and Organizational Agility. California Management Review, 58: 13-35.

Teece, D.J., Pisano, G. \& Shuen, A. 1997. Dynamic Capabilities and Strategic Management. Strategic Management Journal, 18: 509-534.

Tidd, J. 2012. From Knowledge Management to Strategic Competence: Assessing Technological, Market and Organizational Innovation. London, Imperial College Press.

Tranfield, D., Denyer, D. \& Smart, P. 2003. Towards a Methodology for Developing Evidence Informed Management Knowledge by Means of Systematic Review. British Journal of Management, 14: 207-222.

Tushman, M.L. \& O’Reilly, C.A. 1996. The Ambidextrous Organization: Managing Evolutionary and Revolutionary Change. California Management Review, 38: 1-23.
Winterhalter, S., Zeschky, M.B., Neumann, L. \& Gassmann, O. 2017. Business Models for Frugal Innovation in Emerging Markets: The Case of the Medical Device and Laboratory Equipment Industry. Technovation, 66: 3-13.

Yoo, Y. \& Kim, K. 2015. How Samsung Became a Design Powerhouse. Harvard Business Review, 93: 72-12.

Zott, C., Amit, R. \& Massa, L. 2011. The Business Model: Recent Developments and Future Research. Journal of Management, 37: 1019-1042.

\section{About the Authors}

Karl Joachim Breunig is a Full Professor of Strategic Management at the Oslo Business School, Oslo Metropolitan University -OsloMet, where he is heading the research group on Digital Innovation and Strategic Competence in Organizations (DISCO). He received his Ph.D. from BI Norwegian Business School, and holds a MSc from London School of Economics. Prof. Breunig's research concentrates on the interception of strategy and innovation theory, and involves topics such as service- and business model innovation as well as digitalization in knowledge intensive firms.

Tale Skjølsvik is a Full Professor of Technology Management, and the Vice-Dean of Research at the Faculty of Technology, Art \& Design at OsloMet. She holds a Ph.D. in Strategic Management from BI Norwegian Business School and has experience as a management consultant from Bain \& Company and Gemini Consulting. Tale develops and runs executive education within strategic management and digital transformation, consults organizations and does ostensive public speaking. Her research interests concentrate on the strategic management, innovation, digitalization and procurement of knowledge intensive services and firms.

Citation: Breunig, K., and Skjølsvik, T. 2020. Understanding the Strategy-Innovation Link in an Era of Disruptions. Technology Innovation Management Review, 10(8): 4-13.

http://doi.org/10.22215/timreview/1377

Keywords: Conceptual research, disruption, organizational capabilities, structured literature review, strategy-innovation link. 